\title{
CULTURAL HERITAGE PROTECTION ISSUES IN LEŚNICA, THE SETTLEMENT OF WROCŁAW
}

\author{
Alena KONONOWICZ ${ }^{1}$ \\ Wrocław University of Technology \\ Faculty of Architecture, Wrocław, Poland
}

\begin{abstract}
Leśnica, today the settlement on the western edge of Wrocław, formerly was an independent town, located on a previously wooded area, with a linear street system. It developed in the Middle Ages around the castle and church playing a service role for the Silesian Piast court on their way to Legnica and during hunting. In the thirteenth century it received city rights, and lost them in the eighteenth century. After the Piast dynasty had died out, it was sold by John of Luxembourg, and repeatedly changed its owners. In the nineteenth century it developed thanks to the industry, tourism and a convenient railway connection to Wrocław as well as hotel and restaurant facilities. In 1928, Leśnica was incorporated into Wrocław. After the Second World War, it lost its cultural continuity. In the 1970's, middle-heigh and high prefabricated buildings were built in the vicinity of a residential district. At the end of the twentieth and early twentyfirst century, local industries were liquidated, and intensive land development started, causing the systematic blurring of its small-town character and its urban space started to acquire a character of a big city. In 2004, the old part of Leśnica was entered in the Register of Monuments. Also a ring road was planned, moving the cumbersome and dangerous transit traffic away from historic Średzka Street beyond the southern border of the settlement.
\end{abstract}

Keywords: Wrocław, Leśnica, settlement, former small town revalorization

\footnotetext{
${ }^{1}$ Corresponding author: Wrocław University of Technology, Faculty of Architecture, Bolesława Prusa st 53/55, 50-317 Wrocław, Poland, e-mail: alena.kononowicz@ pwr.edu.pl, tel.+48713206231
} 


\section{INTRODUCTION}

Leśnica is no longer an independent and separate town, but the architecture of the settlement and its spatial arrangement needs to be protected and this fact cannot be underestimated.

\section{HISTORICAL BACKGROUND AND SPATIAL DEVELOPMENT}

Leśnica lies on the left bank of the river Bystrzyca, on the western edge of Wrocław, $15 \mathrm{~km}$ away from the Old Town Square. From the north and west, it borders settlements: Marszowice and Żar, from the south - Pustki and Ratyń. The eastern boundary runs along the river Bystrzyca further along streets: Średzka, Majchra, Promenade to Skoczylasa Street, then along streets: Rubczaka and Łączna towards the south-west, crossing the railway tracks near the station Wrocław-Leśnica, then it runs along the bank of the river Leśna tributary of the Bystrzyca. The western border of the settlement is also the border of the town. Its local name is derived from the topographic name of the river Leśna, Leśnica, which means a small river flowing through the forest [1], [8].

Due to the naturally fortified area, in the floodplains of the river, a settlement started here as early as in the early Middle Ages [7], [9]. At the turn of the twelfth and thirteenth centuries, Leśnica belonged to the ruler of Silesia and was the seat of the prince's court, which served as a residential station for Wrocław's princes during their travels from Wrocław through Środa to Legnica, and also it fulfilled an economic function as a management centre of princely estates. The first castle was built as early as in 1132, but historical sources mention Leśnica for the first time only in 1201, under the name Zerwino [7]. In subsequent years, the name of the village sounded as follows: Lesnya, Lesnyc (1226), Lesnitz (1228), Lesnicza (1271, 1289), Lesnnicz (1289), Lesna (1330), Lesnitz (1360), Lessa (1377), Marklissa (1595), Lissa in Schlesien (before 1873), Deutsch Lissa (since 1873), Breslau Deutsch - Lissa (after connecting it to Wrocław in 1928) [4].

It is known that as early as in the twelfth century, there was a castle of Wroctaw Piasts in Leśnica, where the Prince of Silesia Bolesław Wysoki (Bolesław the Tall), Bolesław Krzywousty's grandson, died in December 1201. In subsequent years, the castle was often visited by Henry the Bearded, Bolesław the Tall's son and his wife Hedwig (Jadwiga), later the saint and patroness of Silesia. Also their son, Henry II the Pious issued documents signed in Leśnica. 
In 1261, Leśnica had a mayor, to whom Prince Henry III granted the right to sell goods in Środa Ślaska. The presence of the mayor indicates the urban character of the town and the location on the German law. Urban settlement had been established earlier, which can be concluded from the fact that in 1248 there was a parish church with a pastor. The church was named after Princess Jadwiga, after her canonization in 1267, which was certified in 1299 [8]. Since about the middle of the thirteenth century, a trade settlement developed near the parish church, that maintained an important route from Wrocław to the west, as well as neighbouring villages. In 1289, Prince of Legnica, Henry V, located the town for the second time under German law, and Leśnica is defined as civitas. In the 1760s a customs chamber functioned in Leśnica in the thirteenth century, but it roused strong concern of the city council in nearby Wrocław about their privileges and benefits. As a result, in 1340, the city council of Wrocław bought from Prince Henry VI the right to abolish customs duties in Leśnica and Wrocław. Thus, the customs house in Leśnica was passed to the city council of Wrocław [1],[8]. In 1339, King John of Luxembourg sold Leśnica to Gysconowi de Reste, a Wrocław's burgher, and since then Leśnica became a private estate, and was repeatedly passed to various owners. Leśnica was a lively town at that time. In 1412, at the initiative of the subsequent owner, Michael Bankau - a Wrocław's patrician, founded in Leśnica a large property (Herrschaft), which, in addition to the castle, comprised land property and the town [8].

At the end of the eighteenth century, Leśnica included: a castle (Fig.1), a Catholic church, a farm, a water mill, two inns, 10 houses, 54 households and 7 other apartments. The town had a population of 323 residents who lived of craft, trade and farming. In all the eighteenth-century descriptions and documents, Leśnica is referred to as a village, then the Leśnica's castle was rebuilt, and in the early nineteenth century - majorat Leśnica (with Mokra and Ratyń) was created.

In the first decades of the nineteenth century Leśnica began to change its rural character. A road to Berlin was built in 1822 as well as a railway line Wrocław - Legnica (1844), through Leśnica, Środa Śląska, Malczyce. Since 1845, Leśnica was under the jurisdiction of the national court.

There were here: a post office (1839), an evangelical school with a dormitory for the poor, a Catholic school, a pharmacy (1847) and the castle surrounded by an English landscape park with numerous specimens of trees, attracting Wrocław's citizens for Sunday walks.

The construction of the railway line revived tourist traffic, but also contributed to the development of the industry. In the 1860s, the main street in Leśnica, Średzka Street, was paved . A brickyard was established and then one of the 
largest construction company in Silesia (1870), Eduard Freytag's construction company, which built in Leśnica (among others): a power plant, a new evangelical church (1877), a new building of the post office (1896), and a dance hall (1898) [7].

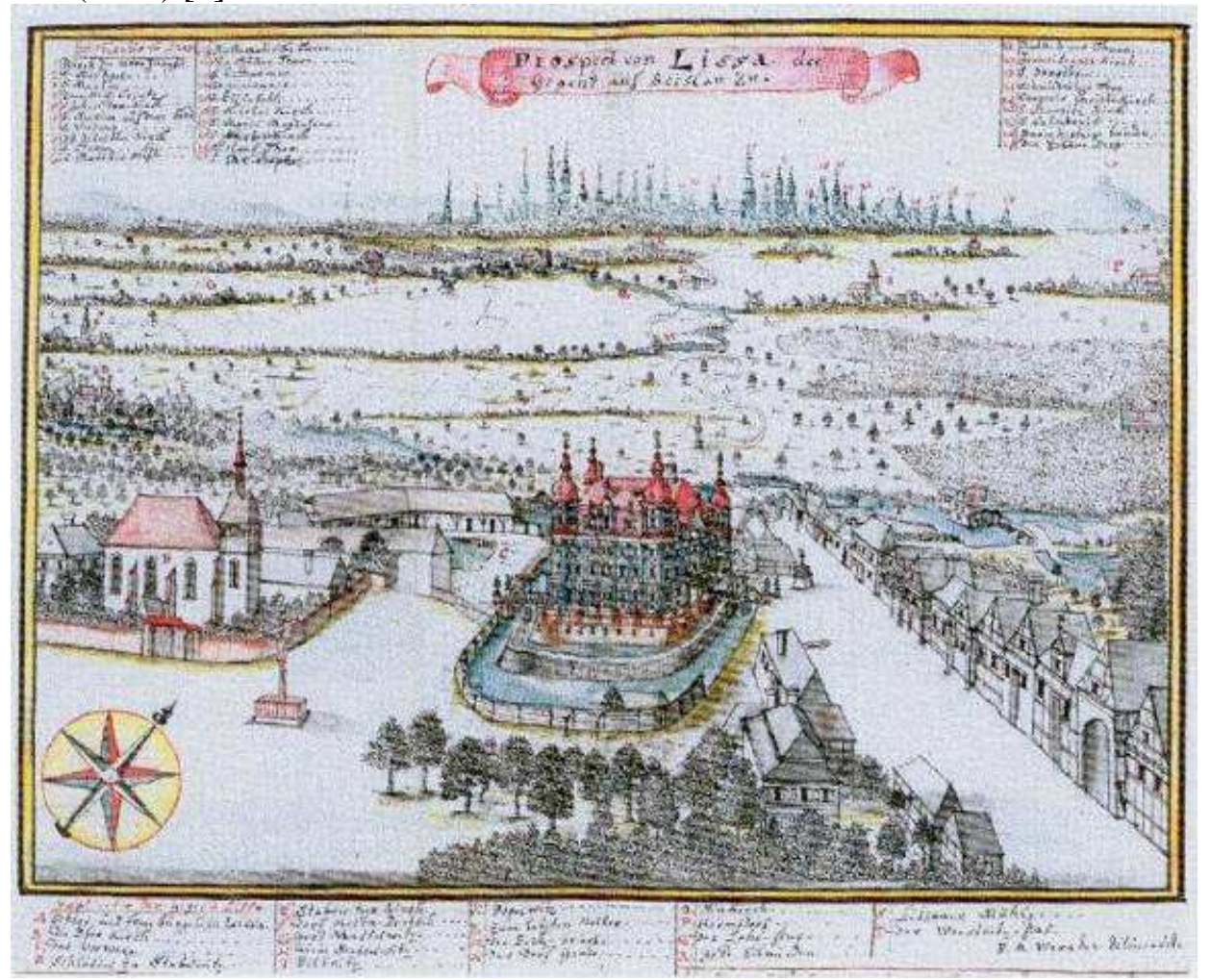

Fig. 1. Leśnica, app. 1750, illustration by Werner [5]

In 1889, a factory producing ceramic tiles was built in Leśnica. In 1922, following the acquisition by the company of Mettlach and further expansion operated under the name Villeroy \& Boch Ceramic Company [3, s.924].

In Leśnica-Złotniki, the largest in the region industrial tannery was set up by H.E. Stürmer in 1892 [3, s.453].

In the second half of the nineteenth century and early twentieth century, Leśnica became an attractive destination of Sunday walks for Wrocław's residents. One of the biggest attractions was the castle park, which was made available to the public, and the scenic woodlands along Bystrzyca (Fig. 2). 


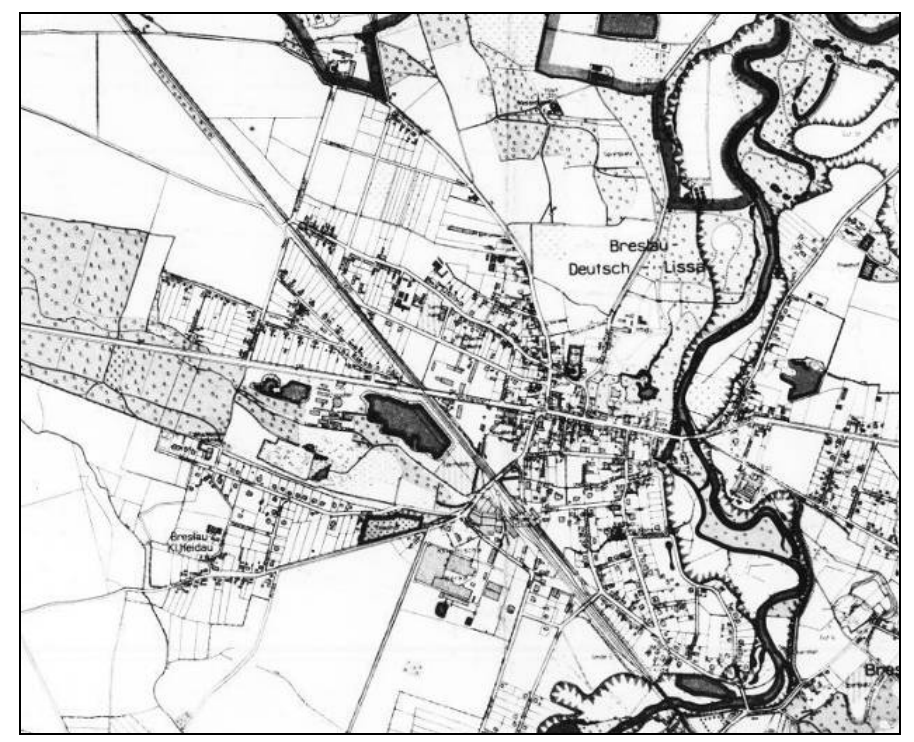

Rys. 2. Leśnica, a map from the late 1920s [5]

In Leśnica had already functioned: restaurants, hotels, entertainment facilities, mainly located in Średzka Street, e.g. the "Deutsches Haus" - a hotel and restaurant, the "Under a White Eagle" ("Zum weissen Adler") and the "Black Eagle" ("Gasthof Schwarzer Adler") - inns, (Fig. 3), or else a dance hall, as well as patisserie and Bruno Schwerin's café. In this time, there were more than 20 trains a day from Wrocław to Leśnica. In the interwar period, there were 3 cinemas: Germania (at 11 Średzka Street) and two in Wolska Street.

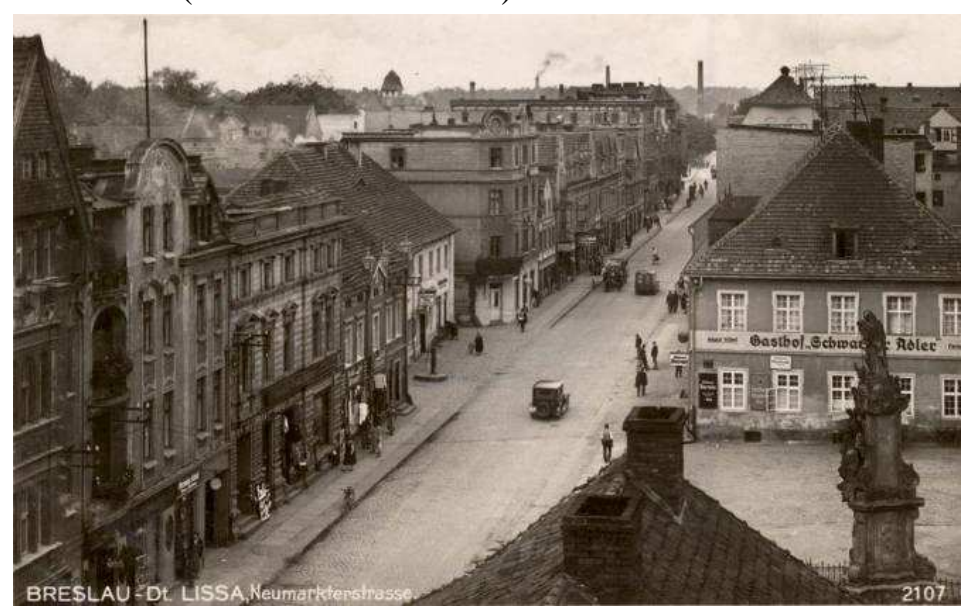

Fig. 3. Leśnica, Średzka Street (bird's eye view) with the entrance to the castle and the inn "Black Eagle". A postcard from approx. 1929, from K. Bykowski's collections 
The subsequent phase of urban development included the area to the south and north from Średzka Street. The southern enclave was a residential area with villas prevailing in the area of streets: Wł. Skoczylasa, Rubczaka, Promenada, Kącka and Łączna (Fig. 4).

This enclave included a post office building, Catholic Church of St. Cross (a former evangelical church) and the railway station.

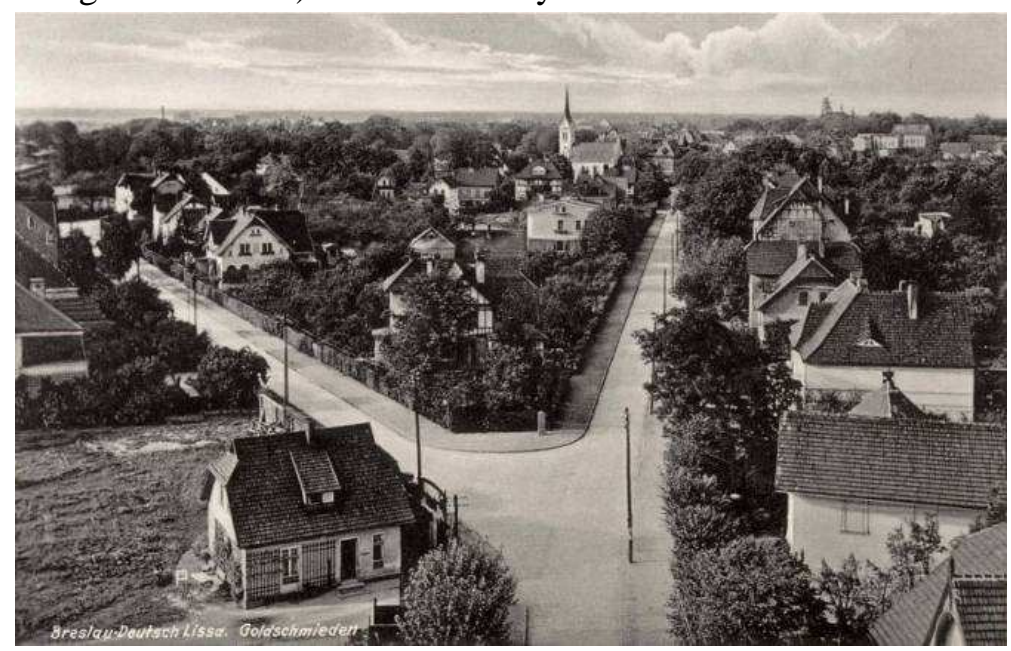

Fig. 4. Leśnica, villas in Kącka and Wł. Skoczylasa streets, a postcard from 1929, from K. Bykowsk's collection

While in the northern enclave, the development took place along the following streets: Dolnobrzeska, Pawła Eluarda, Krępicka and Junacka.

Under the conditions of an architectural contest for the expansion of Wrocław, in 1921, the organizers did not take Leśnica into account, and the westernmost suburban municipalities falling under the competition were: Pilczyce (Pilsnitz), Żerniki (Neukirch) and Muchobór Wielki (Gr. Mochbern). However, architects from Cologne participating in the competition: Wilhelm Arnzt, Karl Dorfmüller and Kurt Meyer - authors of the awarded work No. 27 bearing the motto: Ost West (East - West) - drew their attention to, among others, Leśnica, lying beyond the area of the competition - as a town very attractive for settlement and well-connected with Wrocław. The opinion was welcomed with great interest by the jury and probably contributed to the decision of city authorities to join Leśnica to Wrocław. The opinion resulted in the decisions and actions that followed. In 1924, Leśnica was included in the General Plan of Wrocław, and on April 1, 1928, it was officially incorporated into the city together with 
other Wrocław's suburban municipalities, basing on the Plan as a relevant technical document [6].

\section{HERITAGE PROTECTION ISSUES}

Fortunately, World War II did not caused much damage in Leśnica. New people began to domesticate the town space and start to run businesses and factories. The tannery and the factory producing refractory materials reopened. Life returned to Leśnica. In 1949, a tramway line was built, linking the settlement with the city. Then non-renovated old houses, which had not been repaired since the beginning and decapitalised fast, and sometimes even fell into disrepair, were the problems. In the new regime promoting the "new tomorrow", which was not conducive to preserving historical urban structures, new ideas totally transformed the space. In the 1970s, five- and eleven- storey blocks were constructed among the historic buildings (Fig. 5).

Leśnica has a very diverse and heterogeneous architecture: terraced townhouses are interspersed with detached townhouses, as if dissociated from the context, with rural-type or small-town-type houses, with villas and modernist multifamily houses. Our times added their own forms to this historic crucible. We have some precious infill buildings in the company of historical townhouses, but also tall houses constructed in the technology of prefabricated slabs (the so called large slabs) in the residential area; we also have whole groups of multifamily houses (Fig. 6) as well as housing estates. Perhaps these large projects of housing estates organize the space better, but it is no longer the "Leśnica".

The only common denominator is the greenery, which binds everything and fills the space friendly, also the growing architectural dissonances. Leśnica, incorporated to Wrocław in 1928, became its district, while retaining the street layout characteristic for a small town, with Średzka Street - as the main axis of the historical urban assumption and with its oldest buildings: the castle and the church of St. Jadwiga. Despite the many changes and transformations of the urban fabric, which occurred in the last three decades of the twentieth century and early twenty-first century, the place did not lose its individuality both in social and architectural terms. To this day, Leśnica's residents use to say in their everyday speech "I'm going to Wroclaw," or "I live in Leśnica", or else "I'm going to Leśnica" - unlike the residents of the settlements more united with Wrocław as Sępolno, or Biskupin, who say, "I live in Sępolno" or "I'm going to Biskupin" [5, s. 139]. 


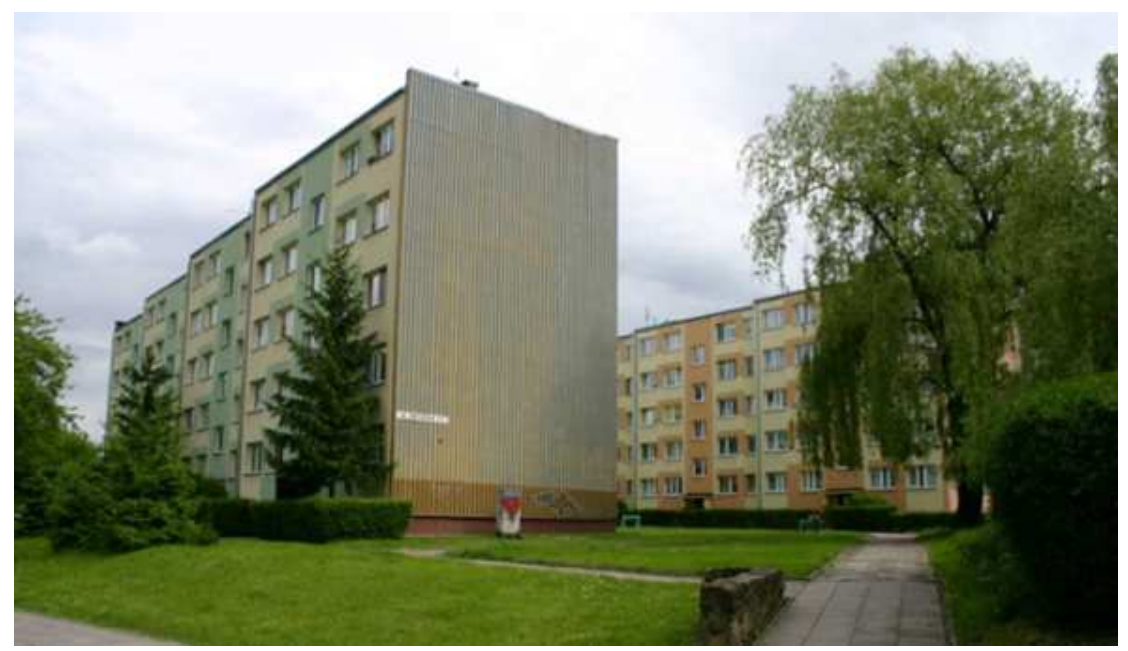

Fig. 5. Leśnica, prefabricated houses in Snycerska and Majchra streets, Phot. A. Kononowicz, 2009

Leśnica, as Wrocław's peripheral housing estate, for years has been treated with neglect, mostly as an area reserve, and its space was unified and "deprived" of its architectural past. Since the beginning of the twenty-first century, it has been experiencing a renaissance. An increased interest in its history has been observed, and the residents have reinforced their identification with the place. Also small-towns buildings have been gaining increasing attention and concern of the municipalities and conservation authorities, which resulted in the fact that the old part of Leśnica was entered in the Register of Monuments in 2004 (Fig. 6).

In local press, it was a dynamic debate on the restoration of Leśnica's autonomy, given municipality Kobierzyce which is rapidly growing "at the gates of Wrocław". According to the author, this idea would not be successful since separated from Wrocław - the main patron and host - Leśnica, for years deprived of identity and a strong industry would not bear its maintenance costs, and the city would lose masses of taxpayers. Besides, as shown by the results of the survey, the residents themselves proved to be reluctant to autonomy. This idea turned out to be an effective marketing slogan and greatly revived the real estate development on the area, with the officials' favourable actions [5, s. 141]. The only thing that is to be done is to protect the remained architectural and urbanistic identity of this old town. The priority task is the commenced by the Company "Wrocław Investments" construction of the bypass, moving the annoying and dangerous transit traffic away from Leśnica thus improving the traffic along historic Średzka Street. 


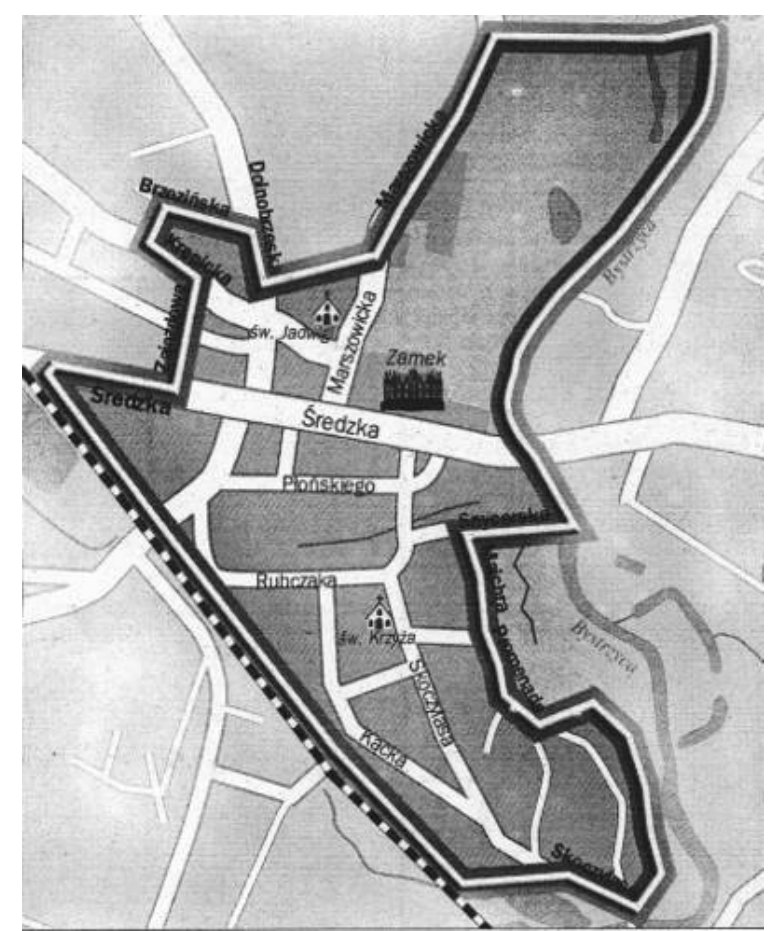

Fig. 6. Leśnica, coverage area of the estate entered in the Register of Monuments, source: "Gazeta Wyborcza" 22.04.2004

\section{CONCLUSIONS}

The today's Leśnica, with the refurbished old buildings and fast growing enclaves of new developments, becomes merely a fashionable, increasingly attractive housing estate since it has lost its multifaceted ties with its rich history. The invasive policy of collective private construction, just as the ruthless policy of prefabricated buildings (the so called "concrete slabs construction") taking place forty years ago, although implemented in different political and economic conditions, without taking into account the historical context, lead to the blurring of the former architectural and spatial character (Fig. 7). 


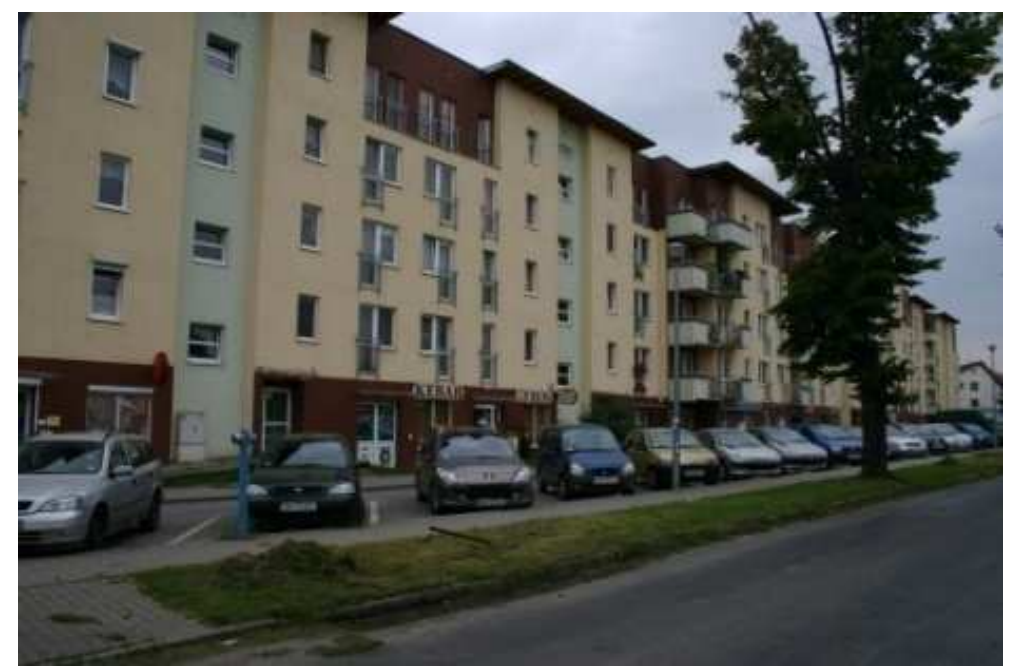

Fig. 7. Buildings along Dolnobrzeska Street, Phot. A. Kononowicz, 2009

\section{REFERENCES}

1. Antkowiak Z.: Stare $i$ nowe osiedla Wrocławia, Wrocław-WarszawaKraków-Gdańsk, 1973, 100-105

2. Bimler K.: Burg Lissa in Breslau, Die schlesischen massiven Wehrbauten, Bd.1: Fürstentum Breslau, Kreise Breslau, Neumarkt, Namslau, Breslau 1940

3. Encyklopedia Wroctawia, red. J. Harasimowicz, Wydawnictwo Dolnośląskie, Wrocław 2001.

4. Goliński M., Ziątkowski L.: Osiedla Wrocławia (kalendaria dziejów do momentu wchtonięcia przez miasto), maszynopis, Wrocław 1997, 101-113;

5. Kononowicz A.: Problematyka dawnych miasteczek - dzisiejszych osiedli mieszkaniowych w granicach Wroctawia, Wydziat Architektury PWr, 2014, dysertacja doktorska (maszynopis)

6. Kononowicz W.: Wroctaw. Kierunki rozwoju urbanistycznego $w$ okresie międzywojennym, Oficyna Wydawnicza Politechniki Wrocławskiej, Wrocław, 1997, 22-24, 81-86.

7. Krzywka Ł., Eysymontt R.: Studium historyczno-urbanistycznokonserwatorskie wraz z wytycznymi konserwatorskimi dla części Zespołu Urbanistycznego Leśnica oraz Parku Leśnickiego, Dla potrzeb planu miejscowego zagospodarowania przestrzennego. Analiza rozwoju zespołu (maszynopis), Wrocław, marzec 2004 
8. Młynarska-Kaletynowa M.: Leśnica, w: Encyklopedia Wroctawia, Wrocław 2006, 477-478.

9. Młynarska-Kaletynowa M.: Wrocław w XII-XVIII wieku. Przemiany społeczne i osadnicze, Wrocław-Warszawa-Kraków-Gdańsk-Łódź, 1986

10. Zipser T.: Aktualna doktryna urbanistyczna wśród ślepych uliczek, w: Urbanistyka $w$ działaniu. Teoria $i$ praktyka, materiały II kongresu Urbanistyki Polskiej pod red. T. Ossowicza i T. Zipsera, „Urbanista”, Warszawa 2006, s.114-121.

\section{PROBLEMY OCHRONY DZIEDZICTWA KULTUROWEGO OSIEDLA LEŚNICA WE WROCŁAWIU}

\section{Streszczenie}

Leśnica, dziś osiedle na zachodnim krańcu Wrocławia, dawniej samodzielne miasteczko, na terenie $\mathrm{z}$ dawna zalesionym, o układzie ulicowym, które rozwinęło się w średniowieczu wokół zamku i kościoła, stanowiąc obsługę dworu Piastów śląskich na trasie do Legnicy. W XIII w. otrzymało prawa miejskie, które utraciło w wieku XVIII. Po wygaśnięciu linii Piastów sprzedane przez Jana Luksemburczyka, zmieniało prywatnych właścicieli. W XIX w. rozwinęło się dzięki przemysłowi, ruchowi wycieczkowemu, dogodnemu połączeniu kolejowemu z Wrocławiem i zapleczu restauracyjno- hotelowemu. W 1928 r. Leśnica zostaje włączona do Wrocławia. Po II wojnie światowej utraciła ciagłość kulturową. W latach 70 . XX w. w sąsiedztwie dzielnicy willowej wzniesiono grupę średnich i wysokich domów z wielkiej płyty. Pod koniec XX i na pocz XXI w. w Leśnicy zlikwidowano przemysł, i rozwinął się intensywny ruch deweloperski, powodujący systematyczne zacieranie małomiasteczkowego charakteru i przekształcanie przestrzeni urbanistycznej na kształt dużego miasta. W 2004 r. stara część Leśnicy została wpisana do Rejestru Zabytków. Zaplanowano także obwodnicę, przenoszącą uciążliwy i niebezpieczny ruch tranzytowy z historycznej ulicy Średzkiej poza południową granicę osiedla.

Słowa kluczowe: Wrocław, Leśnica, osiedle mieszkaniowe, dawne miasteczko, ochrona dziedzictwa

Editor received the manuscript: 28.01 .2015 
